\title{
Equilibrium
}

Quarterly Journal of Economics and Economic Policy

VOLUME 8 ISSUE 4, 2013

ISSN 1689-765X, (Online) ISSN 2353-3293

http://www.equilibrium.umk.pl/

Beck K. (2013), Determinants of Business Cycles Synchronization in the European Union and the Euro Area, "Equilibrium. Quarterly Journal of Economics and Economic Policy", Volume 8, Issue 4, pp. 2548, DOI: http://dx.doi.org/10.12775/EQUIL.2013.025

\section{Determinants of Business Cycles Synchronization in the European Union and the Euro Area**}

\section{JEL Classification: $F 115, F 44, F 47$}

Keywords: Business Cycles Synchronization, Theory of Optimum Currency Areas, Convergence, Economic Specialization, Economic Integration

\begin{abstract}
Further economic and monetary integration in Europe is currently on hold due to the crisis and even questions about the possible exile of Greece. Especially in those conditions, it is important, to see whether integrated Europe can handle future problems and if economic and monetary integration can be helpful or rather more problematic. The main aim of this paper is to check to what degree business cycles are synchronized in the Eurozone and the European Union and what the main determinants of business cycles synchronization are. To achieve this, the following steps have been taken. Firstly, we turn to optimum currency area theory, to see what conditions need to be met, if the European Union and the euro area can use common monetary policy to deal with some economic shocks. Then, all necessary methodological explanations are presented. Later on, the preliminary data analysis is employed to see how business cycles and their determinants were acting during the last 20 years. Finally, panel data analysis is used to check how those determinants actually influence business cycles synchronization. The main finding of the article is that even though business cycles synchronization has been progressing
\end{abstract}

\footnotetext{
(C) Copyright Institute of Economic Research \& Polish Economic Society Branch in Torun Date of submission: March 2, 2013; date of acceptance: August 15, 2013

* Contact: beckkrzysztof@gmail.com, Lazarski University, ul. Świeradowska 43, 02-662 Warszawa, Poland

${ }^{* *}$ Article was prepared within the research project "Convergence in countries and regions of the European Union" funded by the Polish National Science Centre, on the basis of the decision No. DEC-2011/01/N/HS4/03077.
} 
in the European Union and the euro area so does the specialization - divergence in production structure. This may result in less synchronized business cycles in the future.

\section{Introduction}

Further economic and monetary integration in Europe is currently on hold due to the crisis and even questions about the possible exile of Greece. Especially in those conditions it is important, to see whether integrated Europe can handle future problems and if economic and monetary integration can be helpful or rather more problematic. The main aim of this paper is to check to what degree business cycles are synchronized in the Eurozone and the European Union and what the main determinants of business cycles synchronization are. To achieve this following steps are taken. Firstly, we turn to optimum currency area theory, to see what conditions need to be meet, if the European Union and the euro area can use common monetary policy to deal with some economic shocks.

In my analysis, I used yearly data from World Bank, IMF Directions of Trade, EUROSTAT, EU KLEMS, and IMF IFS. All data were available for the European Union and the euro area member countries mostly for the period of 1991-2011. The exceptions are time series of economy structure, which ended in 2007 and convergence, which ended in 2010.

The structure of the paper is as follows: in section one the theoretical framework of traditional and recent optimum currency area concepts is briefly discussed. Section two contains all necessary methodological explanations. In section three the preliminary data analysis is employed to see how business cycles and their determinants were acting during last 20 years. Finally, in section four panel data analysis is used to check how those determinants actually influence business cycles synchronization. Section 5 concludes.

\section{Theory of Optimum Currency Areas}

M. Friedman (1953) initiated an ongoing debate on optimal exchange rate for a given economy. According to his arguments, in conditions of nominal rigidities within the country freely floating exchange rate works as an adjustment mechanism. But as other researchers pointed out, a country itself does not have to be optimal entity for maintaining one currency. Due to these observations, including several conditions is a necessity when defining borders of optimum currency area. Then optimum currency area can be defined as a domain where benefits of adopting common currency outweight 
the costs of lack of monetary autonomy and flexibility of a single country exchange rate (Hallwood, MacDonald 2000).

The so called "old" theory of optimum currency areas was trying to identify criteria that would make abolition of flexible exchange rate and independent monetary policy for a member country as least costly as possible. Perfectly elastic wages and prices can replace flexible exchange rate and independent monetary policy (de Grauwe 2007). Inspired by M. Friedman work R. Mundell (1997) suggested that a country itself did not need to be such an homogenous organism that adjustment processes could be accomplished through exchange rate flexibility and after J. Meade (1957) proposed labor force mobility criterion (Mundell 1961).

R. McKinnon proposed additional criterion - openness of economies of potential currency union member countries (McKinnon 1963). Highly open to each other, the member economies would be characterized with more symmetric distribution of economic shocks. Additionally, high amplitude of variation of exchange rates would strongly disturb inner price stability of such a type of economy (Maes 1992). P. Kennen proposed two additional criteria of optimum currency area. Firstly, covering fiscal and monetary domain (Kennen 1969), which nowadays is described as fiscal federalism - interregional fiscal transfers are becoming adjustment mechanism within common currency area (Kennen 1969) (from regions experiencing expansion to ones experiencing depression) (Fatás 1997). The second criterion proposed by $\mathrm{P}$. Kennes is diversification of production (and consumption) structure, which is reflected with versatile export structure (Bukowski 2007). According to the author, a higher economy diversification structure leads to distribution of sector specific shocks more evenly in the whole economy (Jurek 2004).

All those criteria laid foundations for the old theory of optimum currency areas. The theory had static character and could be helpful in determining whether at a given point of time it is optimal solution for a given country to enter a currency union. On the other hand, development of economic theory, especially the concept of natural rate of unemployment by M. Friedman (1968) and E. Phelps (1967), as well as the influence of rational expectations theory on monetary policy effectiveness (Lucas 1972), decreased the perceived costs of independent monetary policy abolition. Portfolio-balance and assets models indicated that exchange rate could vary a lot from its fundamentals, particularly from international trade variables (Tavlas 1993). In the light of these concepts changes in nominal exchange rate and independent monetary policy have an impact on the economy only in the short run. At the same time, economists started emphasizing qualitative character of monetary unification and large spread of benefits that it brings (Mongelli 2002). 
All this findings led to creation of the "new" theory of optimum currency areas (Tavlas 1993).

Along with the "new" theory of optimum currency areas and more dynamic approach to integration processes within monetary union, two contradicting views on its performance came about. The first one is known as "European Commission View" and states that the more advanced economic integration is, the lower probability of asymmetric economic shocks to occur, they are also expected to be less frequent and less intensive (One market... 1990). This effect is explained by an increased share of intra-industry trade, which leads to a more symmetrical distribution of economic shocks (Horvath, Komarek 1990).

With "European Commission View" is connected endogeneity of optimum currency areas criteria hypothesis created by J. Frankel and A. Rose, who, as they stated, wanted to use "Lucas Critique" (Lucas 1976) to optimum currency area analysis. According to their observations, a progress in economic integration leads to higher business cycles correlation through more symmetric distribution of demand shocks and increase of intra-industry trade (Frankel, Rose 1997). This, in consequences, means that optimum currency area criteria do not need to be fulfilled ex ante, an can be fulfilled ex post. G. Lee and M. Azali came to similar conclusions based on their research on East Asia (Lee, Azali 2009) as well as J. Silvestre, A. Mendonça and J. Passos, who, on the other hand, found out that the increases of international trade intensity had decreasing marginal effect on business cycles synchronization (Silvestre et al. 2007).

Besides intra-industry trade nowadays, economists enlist different origins of optimum currency area endogenity. R. Mundell and R. McKinnon argue that currency unification leads to domestic residents' portfolio diversification by adding foreign bonds or other foreign financial assets (McKinnon 2001). Authors explain this occurrence by elimination of exchange rate risk - this phenomenon is known as risk sharing and was considered the main part of optimum currency area, by its founder R. Mundell in 1973 (Warin et al. 2008). This theoretical view is strongly supported by the data on impact of monetary integration in Europe on international portfolio diversification (Beck, Możdżeń 2011). A higher degree of portfolio diversification leads to more symmetric economic shock distribution. Additionally, participation in common currency area implies inability to use idiosyncratic monetary policy which reduces the probability of asymmetric monetary shocks occurrence in the member states (Beck 2011), and in turn leads to higher business cycles correlation (Babetski 2004). P. de Grauwe argues that difference in a type of monetary regime is considered one of the main sources of asymmetric economic shocks (de Grauwe 2003). 
The second voice considering dynamic approach to common currency area performance is known as "the Krugman's View". P. Krugman argues that in integrating economies four following phenomenon will occur (Krugman 1993): regional specialization, instability of regional export, pro-cyclical capital flows and divergence of long run growth.

T. Bayoumi and B. Eichengreen came to the same conclusions using econometrics. They argued that the United States as a common currency area are characterized by a higher specialization and a higher intensification of asymmetric demand shocks when compared to less integrated European Union (Bayoumi, Eichengreen 1992). Despite strong theoretical and empirical arguments "the European Commission View" and endogenity of optimum currency criteria hypothesis seem to dominate economic debate. This fact can be explained be the latest research contradicting Bayoumi and Eichengreen, but still the hypothesis has not been verified in a definite way (de Grauwe, Mongelli 2005).

\section{Data and Methodology}

Business cycles synchronization approach is used in order to verify, if the euro area and the European Union are optimum currency areas. To justify this choice, two arguments can be raised. The first one considers the lack of proper adjustment mechanisms in absence of flexible exchange rates and independent monetary policy. Neither the euro area, nor the European Union have any institutions that facilitate federal fiscalism. Certainly, the European Union provides redistribution of means as part of the structural policy, and even though this policy can lead to a higher degree of real convergence, it can't function as an adjustment mechanism. Also preliminary data analysis has shown a very low level of labor force mobility. Not only are net migration rates very low (especially in a case of the euro area), but they are also better explained by differences in real wage level, then by changes of unemployment or GDP growth rate and their deviation from natural levels. Finally employing vector autoregression model $(\mathrm{VAR})^{1}$ has shown insufficient degree of wage elasticity, to serve as adjustment mechanism ${ }^{2}$.

As the second reason, one considers the nature of business cycles synchronization. All optimum currency area criterion focused on more symmetrical spread of economic shocks (level of trade and intra-industry trade, economy diversification, degree of specialization), are reflected in a higher business cycles synchronization. Of course, symmetrical spread of economic

\footnotetext{
${ }^{1}$ Model was formulated with endogenous variables representing changes in nominal wage, real wage, unit labor cost and unemployment rate.
} 
shocks and business cycles synchronization are not the same thing, that's why in our analysis some control variables are used in order to correct that difference. Also the business cycles approach allows to include some dynamic aspects of monetary integration, like impact of participation in the monetary union and its effects on convergence, specialization and trade.

To show how business cycles synchronization is determined by the above mentioned factors two approaches are used. Both in the preliminary analysis and panel data approach, there are the same samples used consisting of the European Union and the euro area member countries.

\section{Measures of Business Cycles Synchronization}

In the case of the preliminary data analysis correlation coefficient for a period of ten years is calculated to investigate business cycles synchronization between two countries. The measure is defined as:

$$
r\left(g_{i}, g_{j}\right)=\frac{\sum_{k=1}^{10}\left(g_{i k}-\bar{g}_{l}\right)\left(g_{j k}-\overline{g_{J}}\right)}{\sqrt{\sum_{k=1}^{10}\left(g_{i k}-\bar{g}_{l}\right)^{2} * \sum_{k=1}^{10}\left(g_{j k}-\overline{g_{J}}\right)^{2}}}
$$

where:

$\mathrm{r}\left(\mathrm{g}_{\mathrm{i}}, \mathrm{g}_{\mathrm{j}}\right)$ - GDP growth rates correlation coefficient for countries A and B;

$\mathrm{g}_{\mathrm{ik}}$ - GDP growth rate of country A at year k;

$\mathrm{gj}_{\mathrm{k}}-$ GDP growth rate of country B at year k;

$\overline{g_{l}}$ - average GDP growth of country A;

$\overline{g_{j}}-$ average GDP growth of country B.

To capture effects for euro area as a whole mean value of correlation coefficients is taken, which is defined as:

$$
\text { ear }=\frac{1}{136} \sum_{i=1}^{n-1} \sum_{j=i+1}^{n} r_{i j}
$$

due to fact that euro area has 17 member countries. Analogically, the average value of correlation coefficient for the European Union can be defined as:

$$
\text { eur }=\frac{1}{351} \sum_{i=1}^{n-1} \sum_{j=i+1}^{n} r_{i j}
$$


In the case of panel data approach, the absolute value difference in year to year GDP growth rates between two countries is used. The value of the measure at year $\mathrm{k}$ is defined as:

$$
\bmod _{k}\left(g_{i k}, g_{j k}\right)=\bmod \left(g_{i k}-g_{j k}\right) .
$$

One must admit that this measure is less precise then the other presented previously, but it has the advantage of maintaining the length of times series untouched.

\section{Measures of International Trade}

In order to measure the impact of international trade on business cycles synchronization in panel data approach bilateral values of international trade as percentage of GDP for each pair of countries for every year k were calculated. The measure is defined as:

$$
\operatorname{tradebi}_{i j k}=\frac{\text { Imports }_{i j k}+\text { Exports }_{i j k}}{G D P_{i k}+G D P_{j k}} .
$$

For preliminary data analysis approach in the case of the euro area, the average value of bilateral trade as a percentage of GDP between all member countries was calculated. Measure for the euro area is defined as:

$$
\text { eatrade }_{b i_{i j}}=\frac{1}{136} \sum_{i=1}^{n-1} \sum_{j=i+1}^{n} \frac{\text { Imports }_{i j}+\text { Exports }_{i j}}{G D P_{i}+G D P_{j}},
$$

and for the European Union as:

$$
\text { eutrade }_{b i_{i j}}=\frac{1}{351} \sum_{i=1}^{n-1} \sum_{j=i+1}^{n} \frac{\text { Imports }_{i j}+\text { Exports }_{i j}}{G D P_{i}+G D P_{j}} .
$$




\section{Measures of Economy Structure Similarity}

To measure similarity in economy structure for panel data analysis two bilateral correlation coefficients were calculated. The first is defined as:

where:

$$
\operatorname{Cor}_{i j k}(x)=\frac{\operatorname{cov}\left(x_{i_{k}}^{l}, x_{j}^{l}\right)}{s\left(x_{i}^{l}\right) * s\left(x_{j}^{l}\right)},
$$

$\left(\mathrm{x}_{\mathrm{ik}}\right)^{1}$ - production of sector 1 as percentage of GDP of country $\mathrm{i}$, at year k;

$\left(\mathrm{x}_{\mathrm{jk}}\right)^{1}$ - production of sector 1 as percentage of GDP of country $\mathrm{j}$, at year $\mathrm{k}$;

cov - covariance;

$\mathrm{s}-$ standard deviation.

Second measure is defined as:

$$
\operatorname{Cor}_{i j k}(y)=\frac{\operatorname{cov}\left(y_{i_{k}}^{l}, y_{j_{k}}^{l}\right)}{s(y) * s\left(y_{j_{k}}^{l}\right)^{\prime}}
$$

where:

$\left(y_{i k}\right)^{1}$ - employment of sector 1 as percentage of GDP of country $i$, at year k;

$\left(y_{j k}\right)^{1}$ - employment of sector 1 as percentage of GDP of country $j$, at year $k$.

In preliminary data analysis approach average values of above mentioned measures were calculated. For the euro area and the European Union respectively, they are defined as:

$$
\begin{aligned}
& \operatorname{eaCor}_{i j k}(x)=\frac{1}{136} \sum_{i=1}^{n-1} \sum_{j=i+1}^{n} \frac{\operatorname{cov}\left(x_{i_{k}}^{l}, x_{j_{k}}^{l}\right)}{s\left(x_{i_{k}}^{l}\right) * s\left(x_{j_{k}}^{l}\right)}, \\
& \operatorname{euCor}_{i j k}(x)=\frac{1}{351} \sum_{i=1}^{n-1} \sum_{j=i+1}^{n} \frac{\operatorname{cov}\left(x_{i_{k}}^{l}, x_{j}^{l}\right)}{s\left(x_{i}^{l}\right) * s\left(x_{j}^{l}\right)}, \\
& \operatorname{eaCor}_{i j k}(x)=\frac{1}{136} \sum_{i=1}^{n-1} \sum_{j=i+1}^{n} \frac{\operatorname{cov}\left(y_{i_{k}}^{l}, y_{k}^{l}\right)}{s\left(y_{i_{k}}^{l}\right) * s\left(y_{j_{k}}^{l}\right)},
\end{aligned}
$$




$$
\operatorname{euCor}_{i j k}(x)=\frac{1}{351} \sum_{i=1}^{n-1} \sum_{j=i+1}^{n} \frac{\operatorname{cov}\left(y_{i_{k}}^{l}, y_{j_{k}}^{l}\right)}{s\left(y_{i_{k}}^{l}\right) * s\left(y_{j_{k}}^{l}\right)}
$$

In all cases, the values of proposed measures belong to interval $[-1,1]$, and the higher the value, the more similar economies structures are.

\section{Measures of Specialization}

To measure level of specialization pairwise-Krugman Specialization Indices were employed. In as case of panel data approach, their values are defined as:

$$
K S I_{i j k}^{x}=\sum_{l}^{11}\left|x_{i, k}^{l}-x_{j, l}^{l}\right| \text {, }
$$

for production and:

for employment.

$$
K S I_{i j k}^{y}=\sum_{l}^{11}\left|y_{i, k}^{l}-y_{j, l}^{l}\right| \text {, }
$$

In preliminary data analysis approach average values of above mentioned measures were calculated. For the euro area and the European Union respectively, they are defined as:

$$
\begin{aligned}
& e a K S I^{x}{ }_{i j k}=\frac{1}{136} \sum_{i=1}^{n-1} \sum_{j=i+1}^{n} \sum_{l}^{11}\left|x_{i, k}{ }^{l}-x_{j, l} l_{k}\right| \text {, } \\
& e u K S I^{x}{ }_{i j k}=\frac{1}{351} \sum_{i=1}^{n-1} \sum_{j=i+1}^{n} \sum_{l}^{11}\left|x_{i, k}{ }^{l}-x_{j, l} l_{k}\right| \text {, } \\
& e^{a K S I^{y}}{ }_{i j k}=\frac{1}{136} \sum_{i=1}^{n-1} \sum_{j=i+1}^{n} \sum_{l}^{11}\left|x_{i, k} l-x_{j, l} l_{k}\right| \text {, }
\end{aligned}
$$




$$
\operatorname{eaKSI}_{i j k}=\frac{1}{351} \sum_{i=1}^{n-1} \sum_{j=i+1}^{n} \sum_{l}^{11}\left|x_{i, k}{ }^{l}-x_{j, l_{k}}\right| .
$$

In all cases values of the proposed measures belong to interval $[0,2]$, and the higher the value the less similar two economies are.

\section{Measure of Convergence}

For the panel data approach measure of convergence of two countries is defined as:

$$
\operatorname{conv}_{i j k}=\bmod [\ln (\text { GDPper capita })-\ln (\text { GDP per capita })] .
$$

In the preliminary data analysis approach, the average values of the abovementioned measures were calculated. For the Euro area and the European Union respectively, they are defined as:

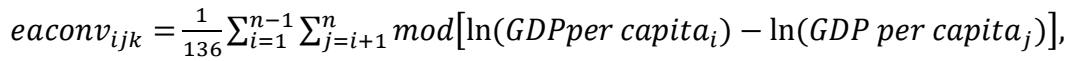

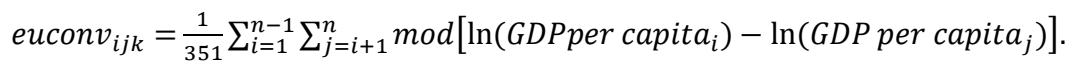

The lower the value of proposed measure, the more converged the two economies are.

\section{Measure of Monetary Union Participation}

In panel data analysis dummy variable was defined to measure the impact of participation in the monetary union. If both countries are monetary union members $=1$; if at least one of them is not $=0$. In the case of preliminary data analysis approach, the average value of dummy variable was calculated - by division by 136 for the euro area and 351 for the European Union. So, the values of the monetary union participation belong to interval $[0,1]$ for the European Union, and $[0,1]$ for euro area. The higher the value of variable, the more countries are the euro area members. 


\section{Control Variables}

The measures presented above, intact with optimum currency areas theory, should reflect economic shock distribution. To measure impact of a monetary union participation, bilateral trade, structure similarities and specialization on business cycles synchronization the macroeconomic policy variables should be defined as control ones. In the panel data analysis, we measure the impact of differences in the monetary policy using the following formula:

$$
m 2=\bmod \left[g_{i}(M 2)-g_{j}(M 2)\right]
$$

where:

$\mathrm{g}_{\mathrm{i}}(\mathrm{M} 2)$ - growth rate of M2 in country $\mathrm{i}$;

$\mathrm{g}_{\mathrm{j}}(\mathrm{M} 2)$ - growth rate of $\mathrm{M} 2$ in country $\mathrm{j}$.

For the preliminary data analysis approach, proper averages were calculated, so that the measures are defined as:

$$
\operatorname{eam} 2=\frac{1}{136} \sum_{i=1}^{n-1} \sum_{j=i+1}^{n} \bmod \left[g_{i}(M 2)-g_{j}(M 2)\right]
$$

and

$$
\text { eum } 2=\frac{1}{351} \sum_{i=1}^{n-1} \sum_{j=i+1}^{n} \bmod \left[g_{i}(M 2)-g_{j}(M 2)\right]
$$

for the euro area and the European union respectively.

To measure the impact of differences in fiscal policy for panel data approach following two measures were calculated:

$$
b d=\bmod \left[\operatorname{dif}\left(b d_{i}\right)-\operatorname{dif}\left(b d_{j}\right)\right]
$$

where:

$\operatorname{dif}\left(\mathrm{bd}_{\mathrm{i}}\right)$ - year to year change in government budget position of country $\mathrm{i}$ as a percentage of GDP;

$\operatorname{dif}\left(\mathrm{bd}_{\mathrm{j}}\right)$ - year to year change in government budget position of country $\mathrm{j}$ as a percentage of GDP, 
and:

$$
g e=\bmod \left[\operatorname{dif}\left(g e_{i}\right)-\operatorname{dif}\left(g e_{j}\right)\right]
$$

where:

$\operatorname{dif}\left(\mathrm{ge}_{\mathrm{i}}\right)$ - year to year change in level of government expenditure of country $\mathrm{i}$ as a percentage of GDP;

$\operatorname{dif}\left(g e_{j}\right)$ - year to year change in level of government expenditure of country $j$ as a percentage of GDP.

For preliminary data analysis as measures of differences in fiscal policy averages for all countries of the Euro area and the European Union were calculated:

$$
\begin{aligned}
& \text { eabd }=\frac{1}{136} \sum_{i=1}^{n-1} \sum_{j=i+1}^{n} \bmod \left[\operatorname{dif}\left(b d_{i}\right)-\operatorname{dif}\left(b d_{j}\right)\right], \\
& \text { eubd }=\frac{1}{351} \sum_{i=1}^{n-1} \sum_{j=i+1}^{n} \bmod \left[\operatorname{dif}\left(b d_{i}\right)-\operatorname{dif}\left(b d_{j}\right)\right], \\
& \text { eage }=\frac{1}{136} \sum_{i=1}^{n-1} \sum_{j=i+1}^{n} \bmod \left[\operatorname{dif}\left(g e_{i}\right)-\operatorname{dif}\left(g e_{j}\right)\right], \\
& \text { euge }=\frac{1}{351} \sum_{i=1}^{n-1} \sum_{j=i+1}^{n} \bmod \left[\operatorname{dif}\left(g e_{i}\right)-\operatorname{dif}\left(g e_{j}\right)\right] .
\end{aligned}
$$

For all presented measures, the lower the value, the lower the differences in economic policy between member countries.

\section{Preliminary Data Analysis}

In order to measure business cycles synchronization, we used yearly data on GDP growth rates from the World Bank. As main determinants suggested by theory of optimum currency areas following variable were chosen: bilateral trade among the member states; correlation of economies structure, Paiwise_Krugman Specialization Index, convergence and monetary union participation dummy variable. To measure bilateral trade yearly, data from the 
IMF Directions of Trade was used, for correlation of economies structure, pairwise Krugman Specialization Index from the EU KLEMS database was taken. To measure convergence, the data from the World Bank was used. Also, control variables were defined: changes in government budget position and the changes in government expenditure, for which yearly data were extracted from the EUROSTAT. To measure differences in monetary policy regime, differences in $\mathrm{M} 2$ growth rates were applied, and the data for that purpose come from the World Bank and the IMF IFS. All data were available for the European Union and euro area member states mostly for the period 1991-2011. The exceptions are time series of economy structure, which ended in 2007 and convergence, which ended in 2010.

\section{Business Cycles Synchronization}

Values of the average correlation coefficients of GDP growth for European Union are presented in Figure 1.

Figure 1. Boxplot for average correlation coefficient for the European Union countries (1991-2011)

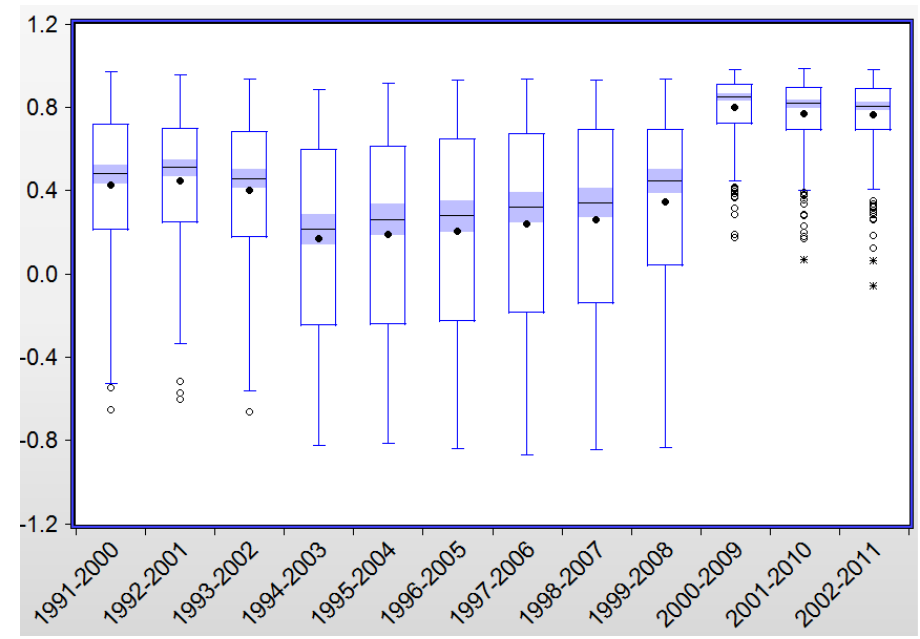

Source: Own calculations based on data from: http://data.worldbank.org/indicator/NY. GDP.MKTP.KD.ZG/countries. 
During first three analyzed periods, the values of average correlation coefficient had been above 0.4 , and then they dropped significantly in the forth period. Since then, we have observed consecutive increase in its value till extreme rise in period between 1999-2009. This high increase might have had its sources on one hand in the creation of the monetary union, and in the financial crisis that had a negative impact on the GDP growth rates of all European Union Countries. Position of inner fences in boxplot suggest that for the whole analyzed period the majority of pairs of countries had positively correlated GDP growth rates. Especially since the period between 1999$200950 \%$ of all pairs of countries had their business cycles correlated at the level above 0.8 .

Even though any clear tendency hasn't appeared, we can observe a steady rise in the average value and stronger concentration of observations since the period between 1994-2003. At this point, we can't add anything more, but some conclusions arise when we compare this values with those of euro area.

Values of average correlation coefficients of GDP growth for the euro area are presented in Figure 2.

Figure 2. Boxplot for average correlation coefficient for euro area countries (19912011)

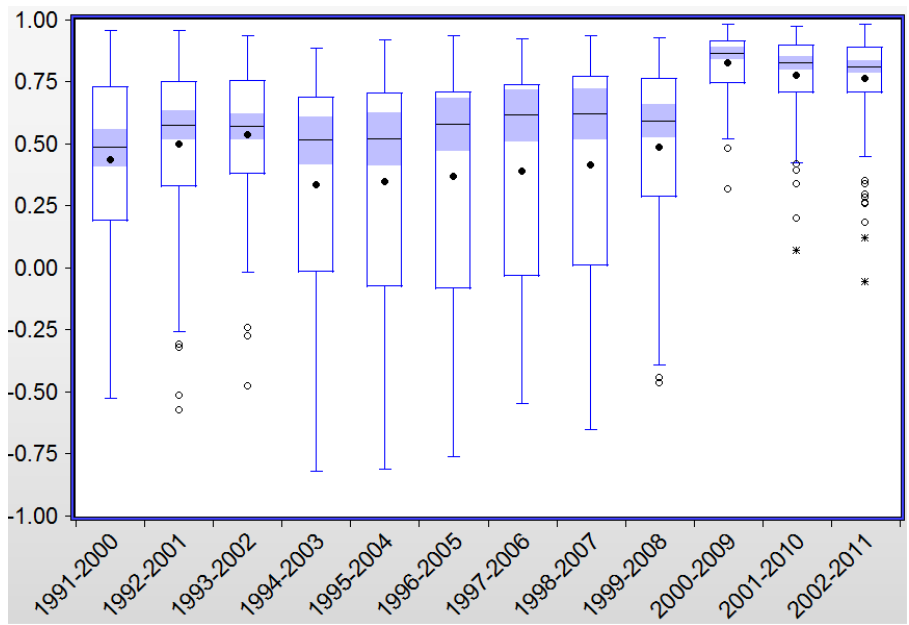

Source: Own calculations based on data form: http://data.worldbank.org/indicator/NY. GDP.MKTP.KD.ZG/countries.

In comparison with the European Union, the values of average correlation coefficient are constantly higher for the entire analyzed period. Skewness is consecutively negative, so as before most pairs of countries have positively 
correlated GDP growth rates. The value of median suggests that $50 \%$ of all pairs of countries had the correlation coefficient above 0,49 and starting since period between 2000 and 2009 even above 0,8 .

A comparison of two box plots allows to draw couple conclusions. Firstly, the changes in the degree of business cycles synchronization are very similar in case of the European Union and the Euro area. The euro area is constantly characterized by higher values of correlation coefficients and concentration. Unfortunately, those differences can be explained by participation, as well as initial differences in the level of integration of the member countries.

\section{Trade, Structure Similarities, Specialization and Convergence}

On average, the value of trade between the European Union countries is equal to roughly $11 \%$ of GDP. Both correlation coefficients and pairwiseKrugman Specialization Indices show rather high similarities between the European Union countries. When we put those values against time, more developed conclusions arise. In Figure 3, the data on the average values of bilateral trade and convergence are presented.

Figure 3. Bilateral trade (1991-2011) and convergence (1991-2010) in European Union countries

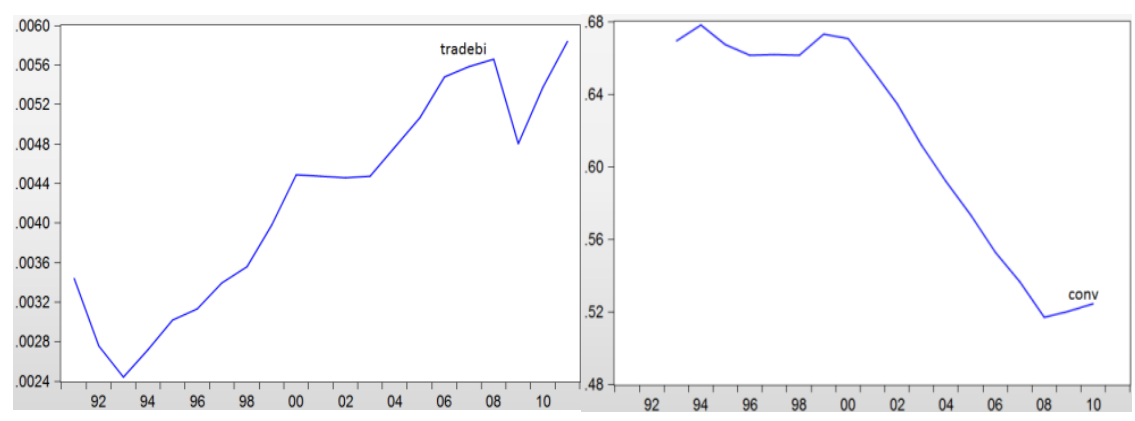

Source: Own calculations based on data from: IMF Directions of Trade statistics; http://www.rug.nl/research/ggdc/data/eu-klems-database; http://data.worldbank.org/topic. 
The value of trade has been steadily increasing over the whole analyzed period. On the other hand, we can observe a very impressive decrease in the differences between GDP per capita level among member countries. If theory predictions are correct, both these factor should lead to higher business cycles synchronization.

In Figure 4, we can observe the values of correlation coefficients and pairwise-Krugman Specialization Index for both production and employment.

Figure 4. Correlation coefficient of economy structure (1991-2007) and pairwiseKrugman specialization index (1991-2007) in the European Union countries

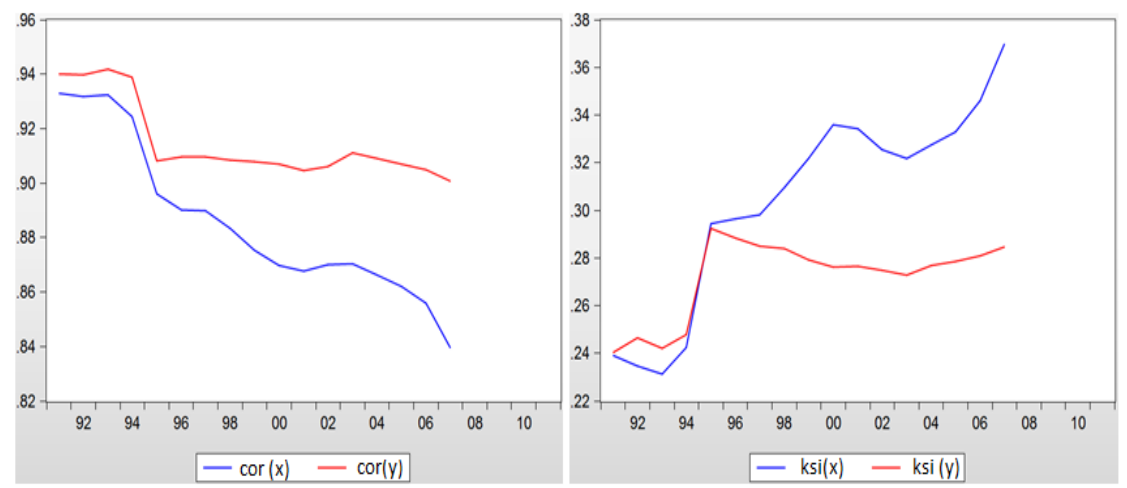

Source: Own calculations based on data from: http://www.rug.nl/research/ggdc/data/euklems-database.

During the entire period, similarities of economies structure were declining - a downfall of correlation coefficient and a rise in pairwise-Krugman Specialization Index for both production and employment. But in both cases, divergence of economy structure is higher in the case of production and employment. This phenomenon can be explained by differences in productivity among sectors. If there are obstacles in free labor factor movements among sectors (like the European Union support for agriculture sector), countries can't effectively specialize in production of goods in which they have comparative advantage. So, one might conclude that removal of these impediments will result in further specialization.

The average value of bilateral trade among the euro area countries is slightly higher than in the case of the European Union. But correlation coefficients and pairwise-Krugman Specialization Indices show slightly lower similarities between the Euro area countries, when compared with the Euro- 
pean Union. In Figure 5, data on average values of bilateral trade and convergence have been presented.

Figure 5. Bilateral trade (1991-2011) and convergence (1991-2010) in the euro area countries

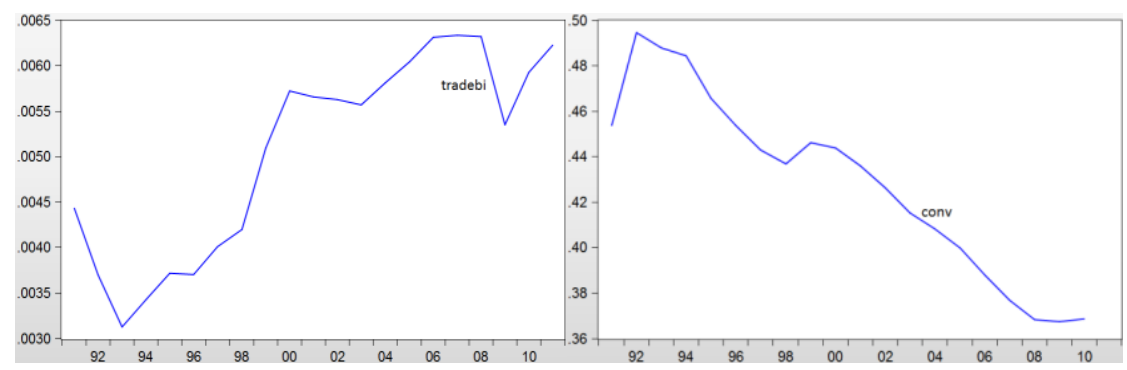

Source: Own calculations based on data from: IMF Directions of Trade statistics; http://www.rug.nl/research/ggde/data/eu-klems-database; http://data.worldbank.org/topic.

International trade among the euro area countries is at a rather steady level, except for two periods. The first one starts in 1999, when average bilateral trade started increasing, and the second one starts in 2008, when trade took a slight drop. The first episode's characteristics can be explained by higher economic integration and formation of a monetary union, and the second one by the crisis and its impact on overall economic activity.

In Figure 6, we can observe values of correlation coefficients and pairwise-Krugman Specialization Index for both production and employment.

Figure 6. Correlation coefficient of economy structure (1991-2007) and pairwiseKrugman specialization index (1991-2007) in the Euro area countries

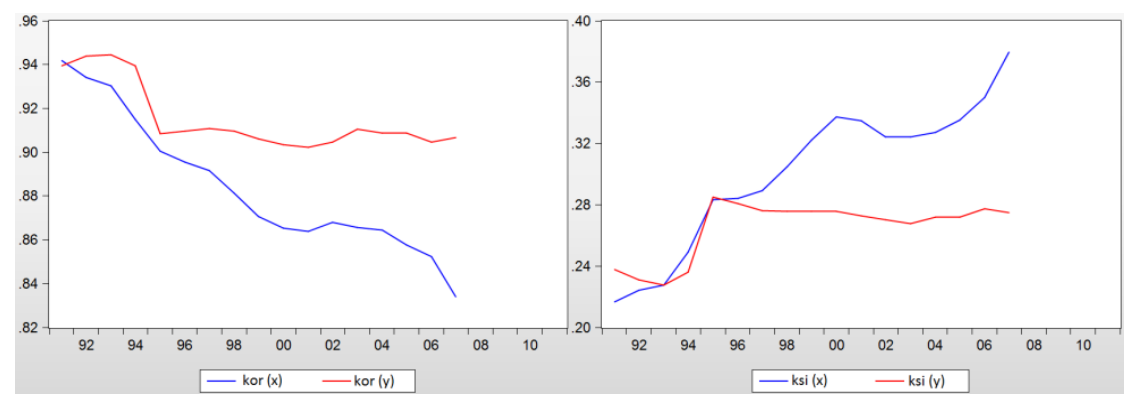

Source: Own calculations based on data from: http://www.rug.nl/research/ggdc/data/euklems-database. 
Like in the case of the European Union, during the entire period the similarities of economies structure was declining - a downfall of correlation coefficient and a rise in pairwise-Krugman Specialization Index for both production and employment. This effect is especially strong for ksi(y), whose values remain stable since 1995. Explanation of differences in values of indices measured in production and employment is the same as for the European Union.

This results seem to support the "Krugman's View". Ongoing economic and monetary integration reduces impediments to trade and investment, so that production is located where comparative advantage and economies of scale are at work. So, in the future both the European Union and the euro area might be more exposed to asymmetrical economic shocks. In this circumstances, one can expect a lower business cycles synchronization. If government limits its involvement in the economy, specialization measured in terms of employment might go even further and lead to more asymmetrical distribution of economic shocks.

\section{Panel Data Approach}

Firstly, panel data approach has been used for all European Union countries. All used time series have proven to be stationary by Levin, Lin and Chu test. Results of estimation are presented in Table 1.

Control variables show positive signs in case of M2 growth rates and changes in government expenditure, which is the result predicted by the economic theory - the smaller the differences in two countries' economic policy the lower the absolute value of their GDP growth rates. On the other hand, differences in the changes of budget deficit position have negative impact on business cycles synchronization. This result might come from the fact that budget deficits reflect both expenditure and revenue side of government activity, and due to that they are strongly dependent on initial expenditure to revenue ratio. So even in the case of countries highly correlated GDP growth rates, might budget position changes might react differently.

Monetary union dummy variable shows negative sign in all estimated equations. This might suggest that when countries form a monetary union risk sharing is prevailing. In such a case, economic shocks of any nature are spreading more evenly among member states. Also, an impact of international trade on business cycles synchronization is positive. High negative value of regression coefficient, show that its impact is very strong. On the other hand, as preliminary data analysis has shown, the level of trade among European union countries is very stable. Thus, further increases in business cycles synchronization might be very hard to accomplish through trade. But 
as preliminary data analysis has shown, monetary union member countries tend to trade on average more with each other. So, further monetary integration might lead to tighter GDP growth correlation, through channel of more internationally diversified national portfolios' structure, as well as through increases in trade volume.

Table 1. Estimation results for European Union

\begin{tabular}{|c|c|c|c|c|c|c|c|c|c|c|c|c|c|c|c|}
\hline & c & bd & mu & $\mathbf{m} 2$ & ge & tr & korx & kory & ksix & ksiy & co & $\mathbf{R} 2$ & $\mathbf{P}(\mathbf{F})$ & DW & Period \\
\hline $\mathrm{a}$ & 2,35 & $-0,17$ & $-0,27$ & 0,04 & 0,10 & $-29,53$ & & & & $-1,76$ & 1,26 & \multirow{3}{*}{0,15} & \multirow{3}{*}{0,00} & \multirow{3}{*}{0,95} & \multirow{3}{*}{$1996-2007$} \\
\hline $\mathrm{t}$ & 15,86 & $-5,39$ & $-2,50$ & 11,72 & 3,76 & $-6,03$ & & & & $-3,72$ & 10,74 & & & & \\
\hline $\mathrm{p}$ & 0,00 & 0,00 & 0,01 & 0,00 & 0,00 & 0,00 & & & & 0,00 & 0,00 & & & & \\
\hline $\mathrm{a}$ & 2,05 & $-0,16$ & $-0,24$ & 0,04 & 0,10 & $-27,45$ & & & $-0,56$ & & 1,20 & \multirow{3}{*}{0,15} & \multirow{3}{*}{0,00} & \multirow{3}{*}{0,94} & \multirow{3}{*}{$1996-2007$} \\
\hline $\mathrm{t}$ & 17,43 & $-5,27$ & $-2,18$ & 11,88 & 3,60 & $-5,63$ & & & $-1,84$ & & 9,65 & & & & \\
\hline $\mathrm{p}$ & 0,00 & 0,00 & 0,03 & 0,00 & 0,00 & 0,00 & & & 0,07 & & 0,00 & & & & \\
\hline $\mathrm{a}$ & 0,72 & $-0,16$ & $-0,22$ & 0,04 & 0,10 & $-28,37$ & 1,29 & & & & 1,28 & \multirow{3}{*}{0,15} & \multirow{3}{*}{0,00} & \multirow{3}{*}{0,95} & \multirow{3}{*}{ 1996-2007 } \\
\hline $\mathrm{t}$ & 2,12 & $-5,29$ & $-2,06$ & 11,67 & 3,58 & $-5,85$ & 3,71 & & & & 10,71 & & & & \\
\hline $\mathrm{p}$ & 0,03 & 0,00 & 0,04 & 0,00 & 0,00 & 0,00 & 0,00 & & & & 0,00 & & & & \\
\hline $\mathrm{a}$ & $-1,29$ & $-0,17$ & $-0,26$ & 0,04 & 0,10 & $-29,91$ & & 3,43 & & & 1,33 & \multirow{3}{*}{0,16} & \multirow{3}{*}{0,00} & \multirow{3}{*}{0,95} & \multirow{3}{*}{ 1996-2007 } \\
\hline $\mathrm{t}$ & $-2,45$ & $-5,43$ & $-2,42$ & 11,37 & 3,80 & $-6,19$ & & 6,21 & & & 11,68 & & & & \\
\hline $\mathrm{p}$ & 0,01 & 0,00 & 0,02 & 0,00 & 0,00 & 0,00 & & 0,00 & & & 0,00 & & & & \\
\hline a & 2,57 & $-0,04$ & $-0,53$ & 0,05 & 0,07 & $-39,63$ & & & & & & \multirow{3}{*}{0,11} & \multirow{3}{*}{0,00} & \multirow{3}{*}{1,4} & \multirow{3}{*}{ 1996-2011 } \\
\hline $\mathrm{t}$ & 40,33 & $-1,85$ & $-5,86$ & 17,76 & 2,86 & $-9,49$ & & & & & & & & & \\
\hline $\mathrm{p}$ & 0,00 & 0,06 & 0,00 & 0,00 & 0,00 & 0,00 & & & & & & & & & \\
\hline $\mathrm{a}$ & 2,75 & & $-0,33$ & 0,04 & 0,04 & $-39,34$ & $-0,56$ & & & & & \multirow{3}{*}{0,11} & \multirow{3}{*}{0,00} & \multirow{3}{*}{0,92} & \multirow{3}{*}{$1996-2007$} \\
\hline $\mathrm{t}$ & 9,85 & & $-3,05$ & 13,90 & 1,99 & $-8,43$ & $-1,79$ & & & & & & & & \\
\hline $\mathrm{p}$ & 0,00 & & 0,00 & 0,00 & 0,05 & 0,00 & 0,07 & & & & & & & & \\
\hline $\mathrm{a}$ & 1,91 & & $-0,35$ & 0,04 & 0,03 & $-35,83$ & & & 1,08 & & & \multirow{3}{*}{0,11} & \multirow{3}{*}{0,00} & \multirow{3}{*}{0,93} & \multirow{3}{*}{ 1996-2007 } \\
\hline $\mathrm{t}$ & 17,33 & & $-3,31$ & 13,87 & 1,93 & $-7,61$ & & & 4,15 & & & & & & \\
\hline $\mathrm{p}$ & 0,00 & & 0,00 & 0,00 & 0,05 & 0,00 & & & 0,00 & & & & & & \\
\hline
\end{tabular}

Source: Own calculations based on data form: http://data.worldbank.org/indicator/NY. GDP.MKTP.KD.ZG/countries; IMF Directions of Trade statistics; http://www.rug.nl/research /ggdc/data/eu-klems-database; http://data.worldbank.org/topic; http://epp.eurostat.ec. europa.eu/portal/page/portal/statistics/themes; http://data.worldbank.org/topichttp://elibrary-dat a.imf.org/FindDataReports.aspx?d=33061\&e=169393; http://epp.eurostat.ec.europa.eu/porta 1/page/portal/statistics/themes.

Analyzing the impact of structure similarities and convergence seem to be a little bit more problematic. This fact is due to negative autocorrelation among those variables reflected in values of Durbin-Watson statistic (DW). In the first four equations, we can see that obtained coefficients for structure correlation and pairwise-Krugman specialization Index for both production and employment have opposite signs to those predicted by the economic 
theory. The impact of convergence measured across countries have positive sign, which is expected one - lower differences in GDP per capita yields higher business cycles correlation. When two countries converge in case of real GDP, their consumption and production structure might too. On the other hand, higher level of GDP in catching up countries, can lead to further specialization. Of course, as preliminary data analysis has shown, "the Krugman's View" and specialization seem to be the case of the European Union. Nevertheless, the impact of convergence on both economy structure and specialization is undoubted. This fact can be seen in the last two equations. When we leave out convergence sign of regression coefficients match the ones predicted by the economic theory. So, definitely, the more similar two economies are, the more synchronized their business cycles.

Secondly, panel data approach has been used for the euro area countries. All used time series have proven to be stationary by Levin, Lin and Chu test. Result of estimation are presented in Table 2.

All conclusions for the European Union can be sustained for the euro area with one very important exception. If we turn to two last equations in Table 2, we will see the impact of specialization on both trade and monetary union participation - when pairwise-Krugman Specialization Index for both production and employment is taken into consideration both of them become insignificant. This can be explained by higher exposal to asymmetric shocks in case of euro area countries. When specialization variable is considered, not the amount of trade among countries is important for business cycles synchronization, but rather the proportion of intra-industry trade in the whole international trade. With higher specialization, the trade structure is changing and countries tend to export goods they have comparative advantage in. So even with higher overall trade values, the differences in the GDP growth rates might remain unchanged. Also, if monetary integration opens possibilities for higher specialization, a positive impact of risk sharing on business cycles synchronization is outweigh, by an area specific industry location. This also confirms "the Krugman's View" on the future of the euro area. Combining those findings with the ones from the preliminary data analysis forms rather unpleasant perspective for the future of the euro area, which will experience lower and lower business cycles synchronization, if tendency is sustained. 
Table 2. Estimation results for euro area

\begin{tabular}{|c|c|c|c|c|c|c|c|c|c|c|c|c|c|c|c|}
\hline & c & bd & mu & $\mathbf{m} 2$ & ge & tr & korx & kory & ksix & ksiy & co & $\mathbf{R 2}$ & $\mathbf{P}(\mathbf{F})$ & DW & Period \\
\hline $\mathrm{a}$ & 0,56 & $-0,12$ & $-0,41$ & 0,04 & $-0,01$ & $-21,40$ & 1,72 & & & & 1,18 & \multirow{3}{*}{0,16} & \multirow{3}{*}{0,00} & \multirow{3}{*}{1,02} & \multirow{3}{*}{ 1996-2007 } \\
\hline $\mathrm{t}$ & 1,06 & $-2,65$ & $-3,15$ & 8,15 & $-0,10$ & $-3,73$ & 3,38 & & & & 4,93 & & & & \\
\hline $\mathrm{p}$ & 0,29 & 0,01 & 0,00 & 0,00 & 0,92 & 0,00 & 0,00 & & & & 0,00 & & & & \\
\hline a & $-2,79$ & $-0,13$ & $-0,50$ & 0,04 & 0,01 & $-21,03$ & & 5,28 & & & 1,38 & \multirow{3}{*}{0,18} & \multirow{3}{*}{0,00} & \multirow{3}{*}{1,03} & \multirow{3}{*}{ 1996-2007 } \\
\hline $\mathrm{t}$ & $-3,30$ & $-2,88$ & $-3,91$ & 8,21 & 0,16 & $-3,72$ & & 6,07 & & & 6,27 & & & & \\
\hline $\mathrm{p}$ & 0,00 & 0,00 & 0,00 & 0,00 & 0,87 & 0,00 & & 0,00 & & & 0,00 & & & & \\
\hline $\mathrm{a}$ & 2,32 & $-0,12$ & $-0,47$ & 0,04 & $-0,01$ & $-19,88$ & & & $-0,30$ & & 0,81 & \multirow{3}{*}{0,16} & \multirow{3}{*}{0,00} & \multirow{3}{*}{1,02} & \multirow{3}{*}{ 1996-2007 } \\
\hline $\mathrm{t}$ & 14,10 & $-2,56$ & $-3,50$ & 8,54 & $-0,11$ & $-3,44$ & & & $-0,68$ & & 3,18 & & & & \\
\hline $\mathrm{p}$ & 0,00 & 0,01 & 0,00 & 0,00 & 0,91 & 0,00 & & & 0,49 & & 0,00 & & & & \\
\hline $\mathrm{a}$ & 2,96 & $-0,13$ & $-0,50$ & 0,04 & 0,00 & $-21,36$ & & & & $-3,19$ & 1,16 & \multirow{3}{*}{0,17} & \multirow{3}{*}{0,00} & \multirow{3}{*}{1,02} & \multirow{3}{*}{ 1996-2007 } \\
\hline $\mathrm{t}$ & 13,39 & $-2,77$ & $-3,94$ & 8,51 & 0,07 & $-3,74$ & & & & $-4,25$ & 5,28 & & & & \\
\hline $\mathrm{p}$ & 0,00 & 0,01 & 0,00 & 0,00 & 0,94 & 0,00 & & & & 0,00 & 0,00 & & & & \\
\hline $\mathrm{a}$ & 2,26 & & $-0,36$ & 0,05 & 0,02 & $-29,25$ & & & & & & \multirow{3}{*}{0,12} & \multirow{3}{*}{0,00} & \multirow{3}{*}{1,2} & \multirow{3}{*}{$1996-2011$} \\
\hline $\mathrm{t}$ & 23,43 & & $-3,45$ & 12,24 & 1,06 & $-6,45$ & & & & & & & & & \\
\hline $\mathrm{p}$ & 0,00 & & 0,00 & 0,00 & 0,29 & 0,00 & & & & & & & & & \\
\hline $\mathrm{a}$ & & $-0,01$ & 0,01 & 0,05 & 0,09 & $-9,41$ & & & & 5,90 & & \multirow{3}{*}{0,02} & \multirow{3}{*}{-} & \multirow{3}{*}{1.00} & \multirow{3}{*}{$1996-2007$} \\
\hline $\mathrm{t}$ & & $-0,27$ & 0,11 & 12,10 & 1,60 & $-1,58$ & & & & 14,83 & & & & & \\
\hline $\mathrm{p}$ & & 0,79 & 0,91 & 0,00 & 0,11 & 0,11 & & & & 0,00 & & & & & \\
\hline $\mathrm{a}$ & & 0,03 & 0,00 & 0,06 & 0,15 & 0,09 & & & 3,70 & & & \multirow{3}{*}{$-0,01$} & \multirow{3}{*}{-} & \multirow{3}{*}{1,04} & \multirow{3}{*}{$1996-2007$} \\
\hline $\mathrm{t}$ & & 0,60 & $-0,02$ & 14,40 & 2,76 & 0,01 & & & 13,28 & & & & & & \\
\hline $\mathrm{p}$ & & 0,55 & 0,98 & 0,00 & 0,01 & 0,99 & & & 0,00 & & & & & & \\
\hline
\end{tabular}

Source: Own calculations based on data form: http://data.worldbank.org/indicator/NY. GDP.MKTP.KD.ZG/countries; IMF Directions of Trade statistics; http://www.rug.nl/research /ggdc/data/eu-klems-database; http://data.worldbank.org/topic; http://epp.eurostat.ec. europa.eu/portal/page/portal/statistics/themes; http://data.worldbank.org/topichttp://elibrary-dat a.imf.org/FindDataReports.aspx?d=33061\&e=169393; http://epp.eurostat.ec.europa.eu/porta 1/page/portal/statistics/themes.

\section{Conclusions}

Generally, business cycles synchronization is tighter in the euro area then in the European Union, but its changes over time exhibit the same tendencies. Since year 2000, in both cases business cycles synchronization (measured by average correlation coefficient of GDP growth rates) has been rising due to monetary integration and increases in international trade value and mostly recent crisis, which affected all European economies. On the other hand, European economies tend to be less and less similar over time, which is proven by lowering of structure correlation coefficient and pairwiseKrugman Specialization Index for both production and employment. What is more, economies similarities in production seem to be dropping at a higher 
pace then those in employment. This can be explained by lower productivity growth in some sectors, due to impediments in intersectional labor mobility. Moreover, real convergence seems to have a positive impact on economies specialization and structure divergence. This fact is especially strongly visible in the case of euro area. Lack of trade barriers and common currency have a positive impact on business cycles synchronization. Unfortunately, they also have strong positive impact on specialization, which leads to lower portion of intra-industry trade in overall trade and further structure divergence. Both this effects outweigh risk sharing and trade influence on business cycles synchronization. All this data seem to support "the Krugman's View" and bring strong argument for the deterioration of business cycles synchronization in the future.

\section{References}

Babetski J. (2004), EU Enlargement and Endogeneity of OCA Criteria: Evidence from the CEECs, Czech National Bank, Research Department, Working Papers nr.2004/02.

Bayoumi T., Eincheergreen B. (1992), Shocking Aspects of European Monetary Integration, NBER Working Paper No. 3949. January.

Beck K. (2011), Akcesja Polski do strefy euro w świetle teorii optymalnych obszarów walutowych - weryfikacja empiryczna [in:] S. Lis (ed.), Kontrowersje wokót akcesji Polski do Unii Gospodarczej $i$ Walutowej, Wydawnictwo Uniwersytetu Ekonomicznego w Krakowie, Kraków.

Beck K., Możdżeń M. (2011), Instytucjonalne przyczyny kryzysu w Stanach Zjednoczonych [in:] A. Prusek (ed.), Wyzwania polityki ekonomicznej $w$ warunkach światowego kryzysu finansowego i gospodarczego, Wydawnictwo Uniwersytetu Ekonomicznego w Krakowie, Kraków.

Bukowski S. (2007), Unia monetarna teoria i polityka, Difin, Warszawa.

de Grauwe P. (2003), Unia Walutowa, Polskie Wydawnictwo Ekonomiczne, Warszawa.

de Grauwe P. (2007), Economics of Monetary Union, Oxford University Press, New York.

Fatás A. (1997), Does EMU Need a Fiscal Federation?, INSEAD and CEPR, Economic Policy Panel, October.

Frankel J., Rose A. (1997), The Endogeneity of the Optimum Currency Area Criteria, CPER.

Friedman M. (1953), The Case for Flexible Exchange Rates, "Essays in Positive Economics", The University of Chicago Press, Chicago.

Friedman M. (1968), The Role of Monetary Policy, „The American Economic Review", Vol. 58, No. 1.

Hallwood C.P., MacDonald R. (2000), International Money and Finance, Blackwell Publishing, Oxford. 
Horvath R., Komarek L. (2002), Optimum currency area theory: an approach for thinking about monetary integration, Warwick Economic Research Papers No 647. Warwick.

Jurek M. (2004), Development of the Optimum Currency Areas theory - some issues, "Poznań University of Economics Review", No 4.

Kenen P. (1969), The Theory of Optimum Currency Areas: An Eclectic View [in:] R. Mundell, A. Swobod (ed.), Monetary Problems in the International Economy, University of Chicago Press, Chicago and London.

Kenen P. (1966), Toward a Supranational Monetary System, "International Economics Workshop", Columbia University.

Krugman P. (1993), Lessons of Massachusetts for EMU, "Adjustment and growth in the European Monetary Union", CEPR, Cambridge University Press, New York.

Lee G., Azali M. (2009), The Endogeneity of The Optimum Currency Area Criteria in East Asia, Discussion paper 15/09. Monasch.

Lucas R. (1972), Expectations and the Neutrality of Money, "Journal of Economic Theory" Vol. 4.

Lucas R. (1976), Econometric Policy Evaluation: A Critique [in:] K. Brunner, A. Meltzer (ed.), The Phillips Curve and Labor Markets, North Holland, Amsterdam.

Maes I. (1992), Optimum Currency Area Theory and European Monetary Integration, "Tijdschrift voor Economie en Management", Vol. XXXVII, No. 2.

McKinnon R. (1963), Optimum Currency Areas, „American Economic Review”, No. 53.

McKinnon R. (2001), Optimum Currency Areas and European Experience, "Stanford University Press", Stanford.

Meade J. (1957), The Balance-of-Payments Problems of a European Free-Trade Area, "The Economic Journal", Vol. 67, No. 267.

Mongelli F.P. (2002), "New" Views on the Optimum Currency Area Theory: What is EMU Telling Us?, European Central Bank Working Papers No. 138. April.

Mundell R. (1961), A Theory of Optimum Currency Areas, „American Economic Review", No. 51.

Mundell R. (1997), Updating the Agenda for Monetary Union, Extended version of a luncheon speech presented at the Conference on Optimum Currency Areas, Tel-Aviv University, December 5.

One market, one money. An evaluation of the potential benefits and costs of forming an economic and monetary union (1990), European Economy No. 44.

Phelps E. (1967), Phillips Curves, Expectations of Inflation and Optimal Unemployment over Time, "Economica", New Series, Vol. 34, No. 135.

Raport na temat petnego uczestnictwa $w$ trzecim etapie Unii Gospodarczej $i$ Walutowej, NBP,

Silvestre J., Mendonça A., Passos J. (2007), The Shrinking Endogeneity of Optimum Currency Areas Criteria: Evidence from the European Monetary Union -A Beta Regression Approach, ISEG Working Paper 022. DE 2007. 
Tavlas G.S. (1993), The 'New' Theory of optimum Currency Areas, "The World Economy", Vol. 16, No. 6.

Tavlas G.S. (2004), Benefits and Costs of Entering the Euro zone, "Cato Journal", Vol. 24, No 1-2.

Warin T., Wunnava P.V., Janicki H.P. (2008), Testing Mundell's Intuition of Endogenous OCA Theory, IZA Discussion Paper No. 3739.September. 